\title{
Book Review: Richard Whittington's Opening Strategy
}

\author{
Reviewed by: \\ Maximilian Heimstädt \\ Weizenbaum Institute, Berlin, Germany \\ m.heimstaedt@udk-berlin.de
}

Opening Strategy: Professional Strategists and Practice Change, 1960 to Today. Richard Whittington. Oxford: Oxford University Press, 2019. pp. 336. ISBN: 9780198738893

We are witnessing a tug-of-war for openness: Pulling towards one side are organizations who describe themselves as being more open than others. Veterans like open source software communities and open innovation platforms have been joined by open government agencies or open hardware manufacturers. Pulling towards the other side, is a growing cadre of skeptics. Facing criticism on the issues of fake news or hate speech, social media platforms that have long promoted the value of openness, now incrementally trade in some of it for increased privacy and control. In academia, the success of reputable open access journals has unintentionally nurtured a shadow industry of predatory publishers. The odds seem fairly even: would you be able to pick a side?

Richard Whittington does. In Opening Strategy, he traces the transformation of strategy practices over the longue dureé. Beginning with the rationalistic strategic planning of the 1960s, he shows how strategy practices have over time become increasingly transparent and inclusive. While the strategic management of the late 1970s brought in middle managers, today's open strategy practices include even more internal and external stakeholders. Whittington makes three overarching arguments: First, openness is not new to the strategy profession. Rather, the historical trajectory since the 1960s shows a gradual but steady opening of strategy-making. 
Second, openness is by no means "simply a matter of growing enlightenment" (p. 264), but results from the piecemeal, entrepreneurial work of corporate strategists and strategy consultants. Third, more open strategy practices can be beneficial beyond the economic performance of the individual organization. Open strategy can lead to greater corporate accountability. It is the finesse of Whittington's analysis, that turns this argument from a philanthropic fairytale into a stimulating reflection about the relation of professional virtue and economic rationality.

The book comprises eight chapters and builds its argument in four steps. Following an introduction (Chapter I), Whittington develops the theoretical framework of his book in Chapter II. For friends (and foes) of practice-based strategy research, his introduction to strategy practices, strategy praxis, and strategy practitioners will hold little surprise. Central to the argument of this book, however, is his addition of the professional field of strategy as a fourth analytical category. Chapter III and IV then zoom in on the field's focal professional groups: corporate strategists and strategy consultants. Instead of portraying them as powerful string pullers (alone), Whittington shows how the work of strategists and consultants has historically been shaped by the precariousness and permeability of their professional field. While corporate strategists are easily sacked in times of economic downswing or leadership change, the "hired guns" (Barley \& Kunda, 2004) of strategy consulting constantly seem to balance on the verge of bankruptcy. Chapter V to VII form the next step of the argument. For each of the "macro practices" (strategic planning, strategic management, open strategy) Whittington weaves together larger organizational, cultural and technological forces with professionals' on-theground tactics to change the practice of strategy-making. In Chapter VIII, the books final section, Whittington presents today's open strategy practices as an instrument for social good beyond profitability of the individual firm and calls upon regulators, professional bodies and academics to 'pull' for openness. 
History matters - when it helps us see contingency and entrepreneurial pursuit where we previously suspected continuity and 'mere' emergence. The parts of the book I liked the most are the ones in which Whittington describes the "rule-making" and "resource-organizing" (Giddens, 1984) through which the strategy professionals sowed uncertainty regarding established practices and gathered support for new ways of making strategy. Not only as a researcher, but also as a teacher of strategy I was fascinated by the many in-depth accounts from the coal face of practice change: How it took several years to develop what today might appear as a 'trivial' portfolio matrix (and how their creators walked the line between elegance and banality). How the practice of scenario analysis was developed by both RAND-affiliated "soldiers of reason" (p. 143) and Stanford-affiliated counterculturalists with a knack for science-fiction literature, extrasensory perception, self-hypnosis, and LSD. It is interesting to learn about the near-academic atmosphere of BCG's Monday-morning meetings of the 1960s, as well as McKinsey's almost industrialist production of 23 (!) articles for Harvard Business Review in the early 1980, to charge their concept of strategic management with academic gravitas.

To explain why strategy professionals change strategy practices, Whittington embarks on a search for professional virtues. Pointing to "glimmers of idealism" (p. 119) in his encounters with strategy professionals, Whittington argues that besides external, economic goods, professionals may also be motivated by internal goods: "the satisfaction of a job well done" (p. 15). For Whittington, the idea(l) of strategy as a vocation, gives hope and justifies a normative stance towards open strategy: By embracing principles of transparency and inclusion, he argues, strategists can contribute to the greater, even societal good of "corporate accountability" (p. 255).

History also matters when it helps us to be more reflexive on how we organize (for) the future. I believe that when it comes to the role of transparent strategy-making for greater organizational accountability, Whittington leaves some potential for reflection untapped. In 
adjacent fields, scholars have already begun to scrutinize the intuitive link between transparency and accountability, especially when mediated by digital infrastructures. Discussing the prevalence of algorithmic systems in organizations and society, digital media scholars Mike Ananny and Kate Crawford (2018) for example describe not one but ten ways in which the transparency ideal is unable to deliver on the aim of accountability. Putting aside for a moment the more general debate on the know-ability of 'black boxed' systems, open strategy scholars should take seriously their concern that if organizational misconduct continues despite transparency, the measure might just further increase public cynicism and indifference.

In her seminal essay on the "tyranny of transparency" Marilyn Strathern (2000, p. 310) already asked: “what does visibility conceal?” In my own work (Heimstädt, 2017), I found that even if professionals sympathize with the transparency ideal, doing transparency may result in various forms of decoupling when the ideal clashes with other professional virtues. For the praxis of open strategy, we should therefore not only look to where the light falls - strategy jams, vlogs and crowdsourcing platforms - but pay attention to forms of opacity and concealment that are enabled by these practices. Especially for the large technology firms, who virtuously sing the song of openness, it seems necessary to study how they strategically herald transparency and inclusiveness to sideline calls for greater accountability.

While the tug-of-war between openness and closure continues, Whittington's book will most likely stimulate debate among academics and professionals. For readers interested in institutional work, Opening Strategy is a masterful demonstration for how a frugal choice and rigorous application of theoretical concepts turns a historical narrative into a more generalized argument about practice change in professional fields. For readers interested in strategy the book shows that thinking about the future is not 'just' a practical skill, but an ongoing intellectual reflection about the role of organizations in society. Sometimes it simply needs some navel-gazing to figure out which way to go. 


\section{Literature}

Ananny, M., \& Crawford, K. (2018). Seeing without knowing: Limitations of the transparency ideal and its application to algorithmic accountability. New Media \& Society, 20(3), 973-989.

Barley, S. R., \& Kunda, G. (2004). Gurus, Hired Guns, and Warm Bodies: Itinerant Experts in a Knowledge Economy. Princeton University Press.

Giddens, A. (1984). The Constitution of Society: Outline of the Theory of Structuration. University of California Press.

Heimstädt, M. (2017). Openwashing: A decoupling perspective on organizational transparency. Technological Forecasting and Social Change, 125, 77-86.

Strathern, M. (2000). The tyranny of transparency. British Educational Research Journal, 26(3), 309-321. 